\title{
Cloud Computing Adoption by Higher Education Institutions of Iraq: An Empirical Study
}

Zaid M. Jawad;

Zaidkubba1@gmail.com;
Iman Kadhim Ajlan;

imykazem73@gmail.com;
Zaid Derea Abdulameer

Zaid.derea@gmail.com

\begin{abstract}
In the last years, a new technology called Cloud computing has been developed. Empirical and previous studies, commonly examined in business field and other domains. In this study, the significant factors that affecting the adoption of cloud computing have been examined using a frequency analysis that have been explored by the previous studies. The results showed that the most effected factors were relative advantage which followed by security and privacy, complexity, innovativeness, and external support. In this study the model of technologyorganization-environment was used to examine the significant factors that affecting the adoption of cloud computing.
\end{abstract}

Keywords: Cloud computing adoption, Education, HEI, TOE

\section{1- Introduction}

Emerging in technology present new opportunities in enhancing education. A range of technology tools enable individuals to meet their requirements and identify the environment in which they work or study. (Masud, Yong, \& Huang, 2012). Cloud computing is a new trend of delivering inforamtion and technology services.(Kuo, 2011). It refers to both the hardware and software that deliverd applications as services over the web(Armbrust, et al., 2010). Although, is consider as a modern trend in Information Technology (IT), that transfers computing and inforamation away from desktop computers into large data centers. 
However, different studies define the cloud computing based on different visions such as service, applications, infrastractures, architecture layers (A. S. Hashim \& Othman, 2014). In this study, the most common definition of the National Institute of Standards and Technology (NIST) has been involved (Mell \& Grance, 2011). On the other hand, services and applications can access at anytime and anywhere to the computing resources through the internet and other networks (Tehrani \& Shirazi, 2014). However, cloud computing works as a technology model for delivering IT services and resources through the internet and on-demand (McKinnie, 2016). Furthermore, the main purpose of it, is to centralized the operations of IT services and link the information with clients over multi services and application within internet or other networks (A. S. Hashim \& Othman, 2014).

The development of the connection speed related to the internet and other networks as well as broadband connection wireless access, has made a new computing model, and interesting alternative in utilizing IT services and resources (Chen \& Almunawar, 2015). Organizations and Instituations are considering the cloud computing adoption as a approach for expenditure decrease and to enable proceses agility (McKinnie, 2016). Moreover, cloud computing is an substitute of deploying services and systems on-premises. Clients do not rquire to setup or evolve computing services and applications in-house (Tehrani \& Shirazi, 2014).The main variances among using cloud computing and evolving a system on-premises is that clients and users are not responsible for processing the actual IT services and applications. The management of IT services related to cost and operational risk would be reduced.

Iraq is a developing country, and to improve the public IT services such as e-governments services need heavy investments in this field (Faaeq, 2015). Adopting cloud computing in the insitiutions will reducing the expenditure of investment in IT services, applications, and infrastructure (Tashkandi \& Al-Jabri, 2015). Thus, the investment in cloud computing represents for HEI in Iraq an opportunity to access new technologies with minimal expertise, expenditure. Moreover, universities and institutions not require to account for the cost of delivering new technology services, support, infrastructure, and other IT utilities. (Katz, Goldstein, Yanosky, \& Rushlo, 2010). Moreover, cloud computing 
introduces to universities more focus on research and learning activities rather than on complex IT infrastructure, software systems, and maintenance (Dwivedi \& Singh, 2016). HEIs in genral is in a constant state of change and development, mainly as a result of substantial challenges arising from efforts in adopting new technologies (Masud, et al., 2012). However, cloud computing enables the HEIs to store their information on an external server that cloud computing provider can be in a different city or even a different country. In contrast, this could present an issue of data risks related to privacy, security concern. (Tashkandi \& Al-Jabri, 2015).

Therefore, this study concentrates on the significant factors of using cloud computing services at HEIs in Iraq. Technology, organization, and environment (TOE) framework has been applied for studying cloud computing adoption in HEI of Iraq. Due to the numerous HEIs in Iraq, and also the unique usages of cloud computing services applications we chose Al- Kut university to do this empircal study. Al- Kut university is one of the government universities in Iraq and has been used cloud computing applications such as google app. Thus, the questioners will be sent to the staff of the university and the data collected will be analyzed by the SPSS program to show the factors that have been more effected of cloud computing adoption.

\section{2- Background}

\section{2-1 Cloud computing concept}

Cloud computing defines as the distribution of IT services and applications over the Internet. Also, it considers as a technology that conjuncting the utility computing, web applications, and services which can be accessed through the Internet (Makoza, 2016). Moreover, in numerous academic studies have been involved the (NIST) definition of cloud computing as part of their studies (Tashkandi \& Al-Jabri, 2015). The definition provided by ( NIST) says that: "Cloud computing is a model for enabling convenient, on-demand network access to a shared pool of configurable computing resources (e.g., networks, servers, 


\section{مجلــــة كليــــة التربيــة}

storage applications and services) that can be rapidly provisioned and released with minimal management effort or service provider interaction". (Jadeja \& Modi, 2012; Mell \& Grance, 2011).

In contrast, cloud service providers can deliver computing resources as a package of software, hardware that include as a platform. Moreover, it considers as alteration from application as a product that is possessed, to application as a service that is carried from enormous data centers to clients over the internet (Abdollahzadegan, 2013). In addition, the cloud services, and computing resources can be accessed via shared servers and networks (Makoza, 2015). Cloud services allow clients to use software and hardware that are run by third parties at remote servers. Cloud services can be classified into "Software as a Service (SaaS), Platform as a Service (PaaS) and Infrastructure as a Service (IaaS)" as shown in table 1 (A. S. Hashim \& Othman, 2014; Low, Chen, \& Wu, 2011; Makoza, 2016)

\begin{tabular}{|l|l|l|}
\hline Service & Description & Examples \\
\hline SaaS & $\begin{array}{l}\text { This category of services concentrates on the } \\
\text { software of IT applications. SaaS offer online } \\
\text { client's interfaces as linking among end users } \\
\text { and institution services. The services and } \\
\text { applications are rentaling through the Internet } \\
\text { by the cloud providers. }\end{array}$ & $\begin{array}{l}\text { Salesforce.com, } \\
\text { Google apps. }\end{array}$ \\
\hline PaaS & $\begin{array}{l}\text { This category of PaaS is to manage, } \\
\text { maintenance, and operate the select information } \\
\text { among different applications, services, and } \\
\text { infrastructures. Hence, it considered as as } \\
\text { Simulated platform provides services and } \\
\text { application over the Internet. }\end{array}$ & \\
\hline IaaS & $\begin{array}{l}\text { This category of SaaS is considers as system } \\
\text { infrastructure. SaaS represents the hardware that } \\
\text { responsible for the database, operating systems, } \\
\text { services, and the network and web requirements } \\
\text { to connect among cloud applications. }\end{array}$ & Amazon, IBM \\
\hline
\end{tabular}

Table (1) shows the summary of cloud services. 


\section{2-2 Cloud computing in HEIs}

HEIs are moving to cloud environment for a variety of reasons, mainly economic (Klug \& Bai, 2015a). Moreover, the cloud environment is proposing a lower cost of ownership model. In contrast, cloud computing services is increasing in HEIs which are associated with the usages of e-learning systems (Klug \& Bai, 2015a). E-learning based on Cloud computing services is now practical for HEI, creating effectiveness in education and management (Klug \& Bai, 2015a). Cloud services is a best solution for researchers and students that have low expenditure services at academic institutions. A virtual environment of computing services could be constructing using cloud computing, particularly in the domains of online education (Al-Zoube, El-Seoud, \& Wyne, 2010; Klug \& Bai, 2015a). Moreover, IT experts believe that institutions based on cloud services will continue to raise and evolve in the next few years (Abdollahzadegan \& Hussin, 2013). Cloud computing services that comprise data hosting, database, and software could be appropriate choice for HEIs. Thus, HEIs could use virtual environment which hosted applications and services in a cloud such as email, file storage, researchs, sharing of documents and database (Makoza, 2016).

However, cloud computing has several advantages, there are also some disadvantages related to this new technology. Various issues that have been examined by other researchers are concerns related to the cloud's copmlixty, security and privacy. (Tehrani \& Shirazi, 2014). These issues can be taken as significant Factors that affecting cloud computing adoption of by HEI.

\section{3- Research Model and Hypothesis:}

\section{- Research Model:}

In this study the significan factors that affecting the adoption of cloud computing have been examined using the technology-organization-environment (TOE) model. The TOE framework is used to describe the factors that have affect the firm's adoption decision (Tornatzky \& Fleischer, 1990). The model states three standard contexts which are technological, organizational, and environmental, affecting the adoption of a new technology in Institution (Makoza, 2016). 
Technological context reflects the available technologies that might be beneficial to the institution in enhancing institution productivity. In contrast, the organizational context is identified in terms of requirments that are available in institution to support the adoption of new technology (Lippert \& Govindarajulu, 2015). Whereas, the environmental context identifies the institution operations which influenced by competitors, and collaborations with the government. The three contexts are summarized following subgroups:

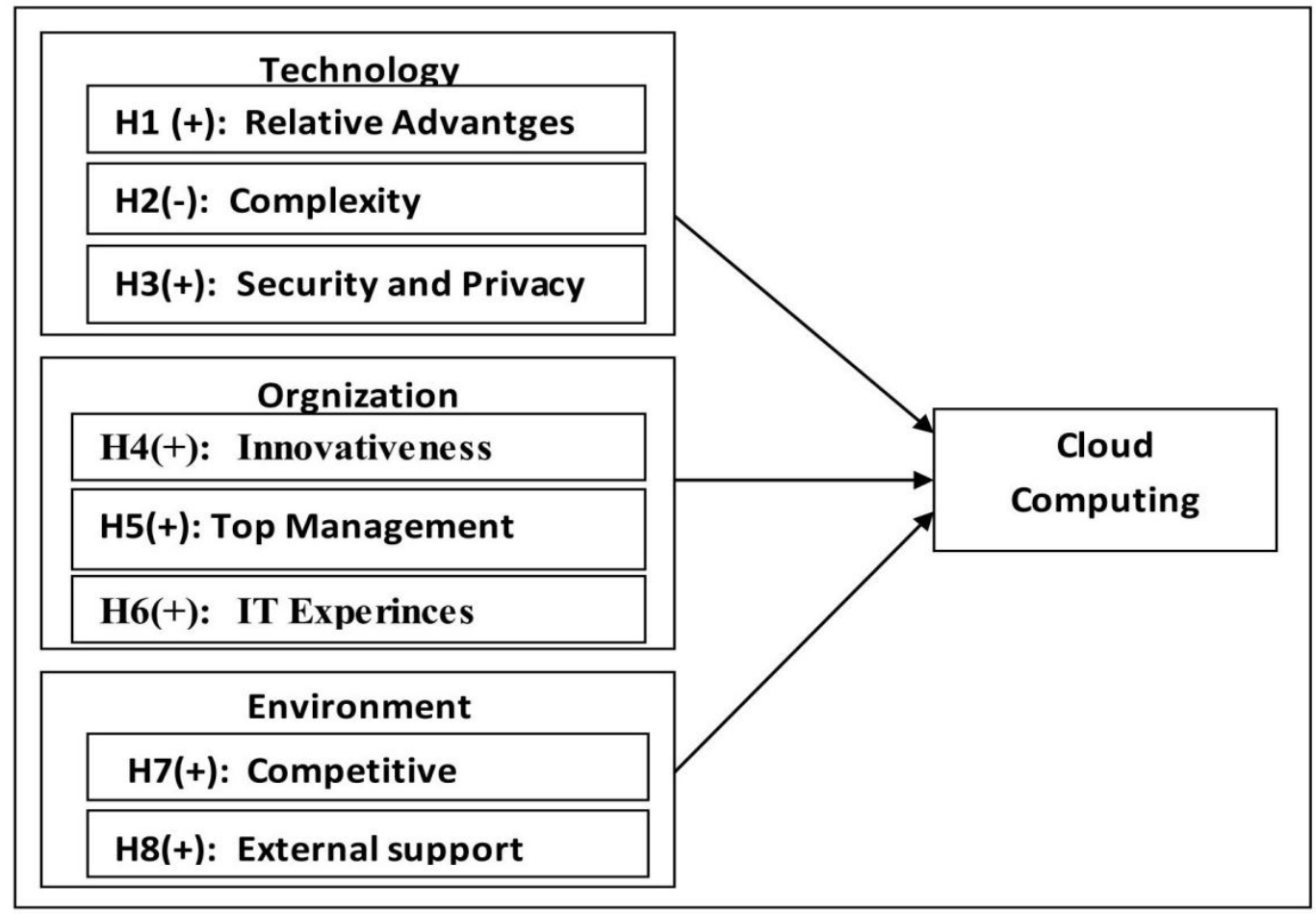

Figure 1. Research Model

3-1 Technological context: This context denotes to the adoption of new technology that using a new services and applications. Several researchers have identified the a variety of factors that affect the adoption of new technology (Kwon and Zmud,1987). Moreover, the adoption of new technology could be effected by 
internal factors of technology resources such as relative advantage, infrastracture, and technical skills (Lippert \& Govindarajulu, 2015). In addition, the adoption of new technologies in institutions might be effected by a mixture of internal and external factors (Makoza, 2016). According to (Alshamaila, 2013), the adoption of new technology has many benefits related to user responsiveness, efficiency and can attain a competitive advantage from improvements in technology. Although, adopting new technology has many advantages for instituations, there are also some drawbacks related to this new technology. A number of the issues that have been discussed by other studies are issues related to the copmlexity, security and privacy. (Tehrani \& Shirazi, 2014). These issues can be taken factors affecting the adoption of Cloud Computing by institutions. The proposed model in this paper identified the technological context into three variables: relative advantage; Complexity; Security and Privacy (Alshamaila, 2013; Lippert \& Govindarajulu, 2015; McKinnie, 2016; Tehrani \& Shirazi, 2014).

However, relative advantages are the supposed benefits from the adoption of new technology in institution (Makoza, 2016). Moreover, it's related with cost reduction to business necessity (Tashkandi \& Al-Jabri, 2015). Also, it's rational that instituations take into consideration the benefits that stem from adopting new technology (Low, et al., 2011). In contrast, the rate of adopting new technology is positively effected by relative advantage whereas it is negatively linked with complexity (Rogers, 2003; Alshamaila, 2013). In contrast, complexity is the supposed difficulty of the adoption of new technologies in institution (Tashkandi \& Al-Jabri, 2015). Institutions might not be able to use an innovation due to the complexity of IT applications and services. Also, this may be due to the fear of using and adopting innovations (Makoza, 2016). On the other hand, security and privacy are identified as an important issue that affecting adopting new technology. This issue is realted to the fear of safe guarding instruments that are storing the information of institution over the internet and transmission media (Lippert \& Govindarajulu, 2015). Moreover, security is about protecting information against unauthorized access, whereas privacy refers to who is permitted to access information. Both Security and privacy are serious concerns for institutions (Alshamaila, 2013). These concerns lead to the following hypothesis: 
H1. Relative advantage that has positively effect with adopting cloud computing. H2. Complexity which is negatively linked with adopting cloud computing.

H3.Security and privacy which are positively linked with adopting cloud computing.

3-2 Organisation context : This context denotes to the impacts that affect the organization decision to adopt new technology. A variety of studies have identified organizational constraints which are affecting the adopting new technology(Lippert \& Govindarajulu, 2015). Moreover, the adoption of innovation in previous studies proposed that top management support, innovativeness, and IT Experinces are significant organizational factors for adopting new technology (Alshamaila, 2013; Lippert \& Govindarajulu, 2015; McKinnie, 2016; Tehrani \& Shirazi, 2014).

Moreover, top management support is important key to the successful organizations that deliver the significance of the new technology to all stakeholders and, at the same time, confirm the availability of the essential services (Alshamaila, 2013). On ther hand, innovativeness define as a variety of the individual's ability to achieve tasks in a better way. Therefore, it is expected that firms whose decision makers more innovative are more expected to adopt new technology (Tehrani \& Shirazi, 2014). In addition, technical experience is vital to run and maintain the services and application that related to cloud services. IT services can become a significant part of institutions activity if they have the essential infrastructure and IT experience (Low, et al., 2011). Thus, organizations that have IT experiences can be more organized for adopting cloud computing (Low, et al., 2011). These concerns lead to the following hypothesis:

H4: Top Management support is positively linked with adopting cloud computing. H5: Innovativeness is positively correlated with adopting cloud computing. H6: IT experiences is positively related with adopting cloud computing. 
3-3 Environmental context: This context refers to the changes in firms to adopt innovation to continue competitive (Makoza, 2016; McKinnie, 2016). The competitive is realted with the adoption of cloud computing, and offers the chance for the institution to recognize its environment. Moreover, institution that depend on other firms should also consider the requirements that are essential to adopt new technologies as a way for dealing with compression (Makoza, 2016). In addition, previous studies proposed that competitive, and external support are important environmental elements for adopting new technology (Alshamaila, 2013; Tehrani \& Shirazi, 2014).

Hence, the two vital elements have been explored their effect on Environmental context. Competitive is the degree of competition between orgnizations in the particular business that the frm runs, and drives firm to be more innovative in order to remain in the industry (Tehrani \& Shirazi, 2014). In addition, competition applies strong pressures on firms to search for new technology to improve their invention (Alshamaila, 2013). Moreover, the experience of strong competition in the institution is essential to the adoption of new technology (Low, et al., 2011). In contrast, the degree of external support provided by cloud services provider is essential to cloud computing adoption (Tehrani \& Shirazi, 2014). In addition, external support explains as "The perceived mportance of external support offered by cloud providers"(Tehrani \& Shirazi, 2014). Hence, These concerns lead to the following hypothesis:

H7: Competitive is negatively linked with adopting cloud computing.

H8: External support is positively correlated with adopting cloud computing. 


\section{4- methodology}

\section{4-1 Population and Sampling:}

In this paper the data gathered using a questionnaire method. The sample of data for this study was selected from Wast university in Iraq. The university has 15 faculties and was established in 2003. In the recent years, the university started deploying the cloud computing via public provider such as Google Apps. Thus, the university was taken as a case study in this research, and the sampling technique was randomly selected. The sample size of this study is 104 respondents divided as (61) academic staff, and (43) non-academic staff. Also, 38 survey items for eight elements in the questionnaire that are actually derived from the literature reviews and adapted to fit the context for this study which is cloud computing adoption (Alshamaila, 2013; McKinnie, 2016; Tehrani \& Shirazi, 2014). The respondents were given two weeks to answer the questionnaires. A total of 104 questionnaires was received complete and usable.

\section{4-2 Research Instrument:}

The study instrument is a questionnaire adapted from other researchers whics is consist of two portions. First part is related to the demographic background information. The second part is related to the factors of cloud computing adoption (Alshamaila, 2013; McKinnie, 2016; Tehrani \& Shirazi, 2014). Five point Likert scales was applied where (1) is strongly disagree and (5) strongly agree. Table 2 below illustrates the measurement and their sources. A total of 38 items which were evolved to examine the eight factors that under investigation. The factors analysis approaches was conducted with the main component items to evaluate the hypothesis validity of the measures. Evaluating was conducted between the factors and their hypotheses that all of the primary factor vlaue should have been greater than 0.5 and had no cross loadings (Hair, Black, Babin, Anderson, \& Tatham, 1998). Eight factors were defined to examine the phenomena in this study. The defined factors are as follows: 
relative advantage (RA), complexity (CMX), security and privacy (SAP), top management support (TMS), innovativeness (INV), IT experiences (ITE), competitive(CMT), and external support (EXS). The Measurement Source of factors are shown in Table 2.

\begin{tabular}{|l|l|l|l|}
\hline contexts & Variables & simple & resource \\
\hline \multirow{5}{*}{ Technology } & $\begin{array}{l}\text { Relative } \\
\text { Advantage }\end{array}$ & RA & $\begin{array}{l}\text { Abrahams, Ophoff, \& } \\
\text { Mwalemba, 2015; Alshamaila, } \\
\text { 2013; McKinnie, 2016; Tehrani } \\
\text { \& Shirazi, 2014) }\end{array}$ \\
\cline { 2 - 4 } & Complexity and & CMX & $\begin{array}{l}\text { (Alshamaila, 2013; A. S. Hashim } \\
\text { \& Othman, 2014; Makoza, 2016; } \\
\text { Tehrani \& Shirazi, 2014) }\end{array}$ \\
\cline { 2 - 5 } & $\begin{array}{l}\text { Security 2015; } \\
\text { Privacy }\end{array}$ & $\begin{array}{l}\text { Abrahams, et al., 2013amaila, 2013; H. S. Hashim } \\
\text { \& Hassan, 2015; Klug \& Bai, } \\
\text { 2015b; Mansour \& Ashour, 2013) }\end{array}$ \\
\hline Organization & Top Management & TMS & $\begin{array}{l}\text { (Abdollahzadegan \& Hussin, } \\
\text { 2013; Alshamaila, 2013; Low, et } \\
\text { al., 2011; Mansour \& Ashour, } \\
\text { 2013) }\end{array}$ \\
\cline { 2 - 5 } & Innovativeness & INV & $\begin{array}{l}\text { (Alshamaila, 2013; McKinnie, } \\
\text { 2016; Wang, 2016) }\end{array}$ \\
\cline { 2 - 5 } & IT experiences & ITE & $\begin{array}{l}\text { (Alshamaila, 2013; Isma'ili, Li, } \\
\text { Shen, \& He, 2016; Mansour \& } \\
\text { Ashour, 2013) }\end{array}$ \\
\hline Environment & Competitive & CMT & $\begin{array}{l}\text { (Alshamaila, 2013; Low, et al., } \\
\text { 2011; Tehrani \& Shirazi, 2014) }\end{array}$ \\
\hline & External Support & EXS & $\begin{array}{l}\text { (Alshamaila, 2013; Isma'ili, et al., } \\
\text { 2016; Tehrani \& Shirazi, 2014) }\end{array}$ \\
\hline
\end{tabular}

Table 2: Source of Measurement. 


\subsection{Validity and Reliability:}

مجلــــة كليــــة التربيــة

The validity of the questionnaire was checked by asking three experts to evaluate and pretest the content of the questions. Their feedbacks and comments were considered for correcting and adjusting the instrument.

\section{Findings:}

\subsection{Demographics of respondents:}

A total of 104 respondents has participated voluntarily in this study. The following table below shows the frequency and percentage of the respondents to their demographic information.

A total of 104 respondents has participated voluntarily in this study. They are mainly in the age between 30 and 40 years $(77$ or $74 \%)$. The respondents included $67(64.4 \%)$ males and 37 (35.6\%) females. Mainly the respondents are staff (43 or $41.3 \%$ ) and they have master degree (49 or $47.1 \%)$. Table 3 shows the demographic information of the respondents.

\begin{tabular}{|l|r|r|r|r|}
\hline \multicolumn{1}{|c|}{ Sex } & $\begin{array}{c}\text { Frequenc } \\
\text { y }\end{array}$ & Percent & Valid Percent & $\begin{array}{c}\text { Cumulative } \\
\text { Percent }\end{array}$ \\
\hline Male & 67 & 64.4 & 64.4 & 64.4 \\
\hline Female & 37 & 35.6 & 35.6 & 100.0 \\
\hline Total & 104 & 100.0 & 100.0 & \\
\hline \multicolumn{5}{|l}{} \\
\hline
\end{tabular}


العــــــدـ الثامن والعشرون

مجلـــة كليــة التريبــة

\begin{tabular}{|c|c|c|c|c|}
\hline Age & Frequency & Percent & Valid Percent & $\begin{array}{c}\text { Cumulative } \\
\text { Percent }\end{array}$ \\
\hline Less than 30 & 9 & 8.7 & 8.7 & 8.7 \\
\hline Between 30 and 40 & 77 & 74.0 & 74.0 & 82.7 \\
\hline Between 40 and 50 & 6 & 5.8 & 5.8 & 88.5 \\
\hline More than 50 & 12 & 11.5 & 11.5 & 100.0 \\
\hline Total & 104 & 100.0 & 100.0 & \\
\hline Employ & $\begin{array}{c}\text { Frequenc } \\
y\end{array}$ & Percent & Valid Percent & $\begin{array}{c}\text { Cumulative } \\
\text { Percent }\end{array}$ \\
\hline Nonacademic staff & 43 & 41.3 & 41.3 & 41.3 \\
\hline $\begin{array}{l}\text { Academic, non } \\
\text { academic staff }\end{array}$ & 28 & 26.9 & 26.9 & 68.3 \\
\hline Academic staff & 33 & 31.7 & 31.7 & 100.0 \\
\hline Total & 104 & 100.0 & 100.0 & \\
\hline Namejob & $\begin{array}{c}\text { Frequenc } \\
y\end{array}$ & Percent & Valid Percent & $\begin{array}{c}\text { Cumulative } \\
\text { Percent }\end{array}$ \\
\hline Dean Ass. & 1 & 1.0 & 1.0 & 1.0 \\
\hline Programmer & 18 & 17.3 & 17.3 & 18.3 \\
\hline Dep. Manager & 21 & 20.2 & 20.2 & 38.5 \\
\hline Manger & 10 & 9.6 & 9.6 & 48.1 \\
\hline Manager Ass. & 13 & 12.5 & 12.5 & 60.6 \\
\hline Lecturer & 21 & 20.2 & 20.2 & 80.8 \\
\hline Engineer & 16 & 15.4 & 15.4 & 96.2 \\
\hline Other & 4 & 3.8 & 3.8 & 100.0 \\
\hline Total & 104 & 100.0 & 100.0 & \\
\hline
\end{tabular}

Table 3 shows the demographic information of the respondents. 


\subsection{Hypotheses testing}

The objective of this study was to find the factors that affect adopting cloud computing services in HEI in Iraq. The findings are presented in the following table. Statistical Package for the Social Sciences (SPSS) version 17.0 was used for data analysis. The result of hypotheses testing is shown in Table 4. The table illustrates that the highest predictors of the adoption are innovativeness (INV), followed by relative advantage (RA), complexity (CMX), and security and privacy (SAP).

\begin{tabular}{|c|c|c|c|c|c|c|}
\hline \multicolumn{7}{|c|}{ Coefficients } \\
\hline \multirow{2}{*}{\multicolumn{2}{|c|}{ Model }} & \multicolumn{2}{|c|}{ Unstandardized Coefficients } & \multirow{2}{*}{$\begin{array}{c}\begin{array}{c}\text { Standardized } \\
\text { Coefficients }\end{array} \\
\text { Beta }\end{array}$} & \multirow[b]{2}{*}{$\mathrm{t}$} & \multirow[b]{2}{*}{ Sig. } \\
\hline & & $B$ & Std. Error & & & \\
\hline \multirow[t]{9}{*}{1} & (Constant) & .554 & .889 & & .623 & .535 \\
\hline & RA & .304 & .150 & .229 & 2.026 & .046 \\
\hline & CMX & $-.126-$ & .108 & $-.091-$ & $-1.172-$ & .244 \\
\hline & SAP & .347 & .213 & .177 & 1.631 & .106 \\
\hline & TMS & .062 & .131 & .056 & .473 & .637 \\
\hline & INV & .622 & .166 & .442 & 3.747 & .000 \\
\hline & ITE & $-.049-$ & .178 & $-.031-$ & $-.273-$ & .786 \\
\hline & CMT & $-.007-$ & .178 & $-.004-$ & $-.040-$ & .968 \\
\hline & EXS & .161 & .142 & .097 & 1.135 & .259 \\
\hline & ant & & & & & \\
\hline
\end{tabular}

Table 4: factors affect adopting Cloud Computing.

The result of hypotheses testing illustrated that the relative advantage adopting cloud computing ( $\mathrm{RA}=0.04, \mathrm{P}$-value $<0.5)$. Thus, $\mathrm{H} 1$ is supported. The second, hypotheses relating to the effect of complexity on the cloud computing adoption were found significantly ( $\mathrm{B}=0.24)$, $\mathrm{P}$-value $<0.5)$. Thus, $\mathrm{H} 2$ is supported. Other factors of TOM such as security and privacy $(B=0.1$, P-value $<0.5)$ were found significant. Thus, the $\mathrm{H} 3$ is supported. On the other hand, top management support $(B=0.63$, P-value $<0.5)$ were found not significant. Thus, $\mathrm{H} 4$ is not supported. The findings of regression analysis illustrated also that the effect of the high inventiveness of adopting cloud computing services is significant $(B=0.00, P$-value 604 
$<0.5)$. Thus, H5 is supported. Similarly, the effect of IT experience $(\mathrm{B}=0.78, \mathrm{P}-$ value $<0.5$ ) was not a significant effect of adopting cloud computing services. Thus, H6 is not supported. The findings showed that competitive of the cloud computing affects not significantly the adoption of cloud computing services $(\mathrm{B}=$ 0.96, P-value <0.5). Thus, $\mathrm{H7}$ is not supported. External support was proposed as a direct determinant of the adoption of cloud computing services. The findings showed that external support is a lower factor that not affects the adoption of cloud computing services $(B=0.25$, $\mathrm{P}$-value $<0.5)$. Thus, $\mathrm{H} 8$ is supported. Table 7 shows a summary of the hypothesis testing. The table shows the beta value which indicates the size of effect along with the P-value of the relationship. It shows also the status of the hypothesis based on the P-value which supposed to be less than 0.5 for the hypothesis to be accepted.

\section{Conclusion:}

This study was conducted to identify the significant factors that affect adopting cloud computing of HEI in Iraq. Al Kut University in Iraq was a case study and their staff were the respondents to this study where data was collected from (104) respondents. The findings indicated that Relative Advantage, Security and Privacy of using the cloud computing services, the complexity of usages, Innovativeness, and external support are most effecting factors of adopting cloud computing. On the other hand, the top management support, IT experience, and competitive are not significant factors of adopting cloud computing. The findings of the study are comprehensive for the universities in Iraq, which share with Wast University similar characteristic. The study is based on the perception of Iraq respondents and the situation in Iraq. For future work, it is recommended that more factors need to be identified on the technology adoption in general and on cloud computing adoption in particular. In addition, future work could extend the findings of the study and conducted another study in different fields to generalize the finding of the study. 


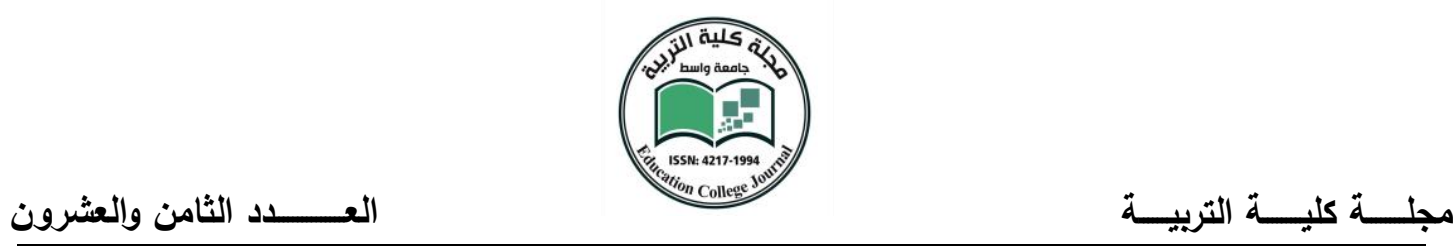

\section{References}

Abdollahzadegan, A., \& Hussin. (2013). The organizational critical success factors for adopting cloud computing in SMEs. Journal of Information Systems Research and Innovation (JISRI), 4(1), 67-74.

Abrahams, O., Ophoff, J., \& Mwalemba, G. (2015). Cloud Computing Adoption for Business Development: A TOE Perspective.

Al-Zoube, M., El-Seoud, S. A., \& Wyne, M. F. (2010). Cloud computing based e-learning system. International Journal of Distance Education Technologies (IJDET), 8(2), 58-71.

Alshamaila, Y. Y. (2013). An empirical investigation of factors affecting cloud computing adoption among SMEs in the North East of England.

Armbrust, M., Fox, A., Griffith, R., Joseph, A. D., Katz, R., Konwinski, A., et al. (2010). A view of cloud computing. Communications of the ACM, 53(4), 50-58.

Chen, C. K., \& Almunawar, M. N. (2015). Cloud Computing in Higher Education. Impact of Economic Crisis on Education and the Next-Generation Workforce, 285.

Dwivedi, S. K., \& Singh, B. (2016). Use Cloud Computing in the Fields of Higher Education.

Faaeq, M. K., Alqasa, K., \& Al-Matari, E. M. (2015). Technology Adoption and Innovation of E-Government in Republic of Iraq. Asian Social Science, 11(3), 135.

Hair, J. F., Black, W. C., Babin, B. J., Anderson, R. E., \& Tatham, R. L. (1998). Multivariate data analysis . Uppersaddle River. Multivariate Data Analysis (5th ed) Upper Saddle River.

Hashim, A. S., \& Othman, M. (2014). Cloud Computing Adoption by Universities: Concepts and Review. Int. J. Sci. Res, 3(2), 348-353.

Hashim, H. S., \& Hassan, Z. B. (2015). Factors That Influence The Users' Adoption Of Cloud Computing Services At Iraqi Universities: An Empirical Study. Australian Journal of Basic and Applied Sciences, 9(27), 379-390.

Hussin, A. A. A. R. C. The Organizational Critical Success Factors for Adopting Cloud Computing in SMEs. INFORMATION SYSTEMS RESEARCH AND INNOVATION.

Isma'ili, A., Li, M., Shen, J., \& He, Q. (2016). Cloud computing adoption determinants: an analysis of Australian SMEs. 
Jadeja, Y., \& Modi, K. (2012). Cloud computing-concepts, architecture and challenges. Paper presented at the Computing, Electronics and Electrical Technologies (ICCEET), 2012 International Conference on.

Katz, R., Goldstein, P., Yanosky, R., \& Rushlo, B. (2010). Cloud computing in higher education. Paper presented at the EDUCAUSE.[Online],[Retrieved October 5, 2010], http://net. educause. edu/section_params/conf/CCW.

Klug, W., \& Bai, X. (2015a). Factors affecting Cloud Computing adoption among Universities and Colleges in the United States and Canada. Issues in Information Systems, 16(3), 1-10.

Klug, W., \& Bai, X. (2015b). FACTORS AFFECTING CLOUD COMPUTING ADOPTION AMONG UNIVERSITIES AND COLLEGES IN THE UNITED STATES AND CANADA. Issues in Information Systems, 16(3).

Krejcie, R. V., \& Morgan, D. W. (1970). Determining sample size for research activities. Educ psychol meas.

Kuo, M.-H. (2011). Opportunities and challenges of cloud computing to improve health care services. Journal of medical Internet research, 13(3), e67.

Lippert, S. K., \& Govindarajulu, C. (2015). Technological, organizational, and environmental antecedents to web services adoption. Communications of the IIMA, 6(1), 14.

Low, C., Chen, Y., \& Wu, M. (2011). Understanding the determinants of cloud computing adoption. Industrial management \& data systems, 111(7), 1006-1023.

Makoza, F. (2016). Cloud computing adoption in Higher Education Institutions of Malawi: An exploratory study. colputing and ICT Research 9(2), 37-54.

Mansour, A. J., \& Ashour, Y. H. (2013). The Adoption of Cloud Computing Technology in Higher Education Institutions: Concerns and Challenges.

Masud, M. A. H., Yong, J., \& Huang, X. (2012). Cloud computing for higher education: a roadmap. Paper presented at the Computer Supported Cooperative Work in Design (CSCWD), 2012 IEEE 16th International Conference on.

McKinnie, M. (2016). Cloud Computing: TOE Adoption Factors By Service Model In Manufacturing.

Mell, P., \& Grance, T. (2011). The NIST definition of cloud computing.

Tashkandi, A. N., \& Al-Jabri, I. M. (2015). Cloud computing adoption by higher education institutions in Saudi Arabia: an exploratory study. Cluster Computing, 18(4), 1527-1537. 
Sداد الثامن والعشرون

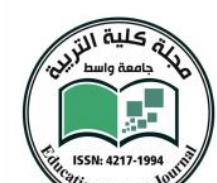

Tehrani, S. R., \& Shirazi, F. (2014). Factors influencing the adoption of cloud computing by small and medium size enterprises (SMEs). Paper presented at the International Conference on Human Interface and the Management of Information.

Thong, J. Y. (1999). An integrated model of information systems adoption in small businesses. Journal of management information systems, 15(4), 187-214.

Tornatzky, L., \& Fleischer, M. (1990). The process of technology innovation, Lexington, MA. Lexington Books. Trott, P.(2001). The Role of Market Research in the Development of Discontinuous New Products. European Journal of Innovation Management, 4, 117125.

Wang, J. (2016). Critical Factors for Personal Cloud Storage Adoption in China. Journal of Data and Information Science, 1(2), 60-74. 